\title{
DEIXIS IN THE SONG LYRIC "LEVEL OF CONCERN" BY TWENTY ONE PILOTS
}

\author{
Siti Nurjamilah ${ }^{1}$, Efransyah $^{2}$ \\ 1,2 IKIP Siliwangi \\ ${ }^{1}$ sitinurjamilah26@student.ikipsiliwangi.ac.id, ${ }^{2}$ efransbae@gmail.com
}

\begin{abstract}
The title of this research is deixis in the Song Lyrics "Level of Concern" by Twenty One Pilots. The objectives of this research are to identify the type of deixis and to find out the dominant types of deixis that are mostly used in the song lyrics entitled Level of Concern. This research used descriptive qualitative method. The researchers took the data from (Joseph, 2020) of the song lyric entitled "Level of Concern" by Twenty One Pilots, for it describes the current world situation, and the lyrics of the song contains a wide range of deixis that have attracted the researchers to examine this song. After conducting this research, the researchers concluded that three types of deixis namely personal, spatial, and temporal deixis. Personal deixis divided into three parts: the first person as speaker, the second person as hearer and the third person as others, with 77 words in that song. Temporal deixis showed a certain period of time which consist of 3 words, and the spatial deixis describes the location in a conversation which consist of 2 words. The major type from the whole data are personal deixis, because they represent the singer and the message which wanted to be delivered to the listeners.
\end{abstract}

Keywords: Pragmatic, Deixis, Song Lyric

\section{INTRODUCTION}

Language is an important role in human life, such as thinking and communicating. Humans need to communicate with other humans using language. If there is no language, human cannot share their experiences, ideas, or arguments with one each other. It is very required for communication to express idea and feeling such as think, emotions, and solving the problems. According to Todd (1987) cited in (Nurjanah, et. al., 2018) says that language is a system of signals by which we to transmit the knowledge. Without language, we have a lot of circumspections to go through our lives in the world. In other words, language is a communication system based on the compound of words into sentences.

As part of linguistics it is classyfied becomes two kinds namely, micro and macro lingustics. Micro lingusitic discusses about the internal element of the language itself such as phonology, morphology, syntax, and semantics. While the second one discusses internal language related to the phenomenon in the society such as Pragmatics, Discourse analysis, Sociolinguistics, and others. According to Huang (2007) cited in (Wiguna, et. al., 2018) "Pragmatics is an integrated study of meaning based on or in accordance with use of language". It develops in linguistic to study the language expression in several way during the speaker and hearer know what they are doing. The main topics discussed in it included implicature, speech acts, presupposition, and deixis.

According to Saputri (2015) on (Liawati, et. al. 2020) states that deixis is to do with an determinate that can be resolved when the researcher looks at the context, and particularly at the three forms of the context who the speaker is, where and when the sentence is uttered. 
Jumanto (2014) in (Liawati, et. al. 2020) also states that deixis is used to denote the elements in a language which refer directly to the situation. From the text above, it can be concluded that deixis is centered on analyzing words, phrases and utterances such as person, place, and time when the speaker is talking to the listener.

\section{Deixis}

Deixis is constantly found in everyday or in a text, for instance in short stories, songs, movies, etc. The articulations in a song frequently utilizes deixis for to demonstrate the a state of personal deixis, spatial deixis and temporal deixis. According to (Yule \& Stalnaker, 1996) in (Setiakawanti \& Susanti, 2018) deixis is pointing at something through language. Deixis is a significant field concentrated in pragmatics, semantics and phonetics. In this study, the researchers focused on personal deixis, spatial deixis and temporal deixis in a song lyric entitled "Level of Concern" by Twenty One Pilots. Deixis is the study of deictic or index expressions in language, alike "you", "now", "today". It can be obesrved as a special type of grammatical property served in the familiar categories of person, place, time and so on (Levinson (2004) in (Lugina, et. al., 2019).

\section{Types of Deixis}

a) Personal Deixis

Cruse (2006, p. 127) in (Nasution, et. al., 2014) states that person deixis words include pronouns (I, You, We, They, She, He, It, Me, Them, Him, Us; Yours, Mine, Yourself, Myself, Hers, Herself, Himself, Themselves, Itself, Ourselves), verb inflection (You like, I like, She or He likes), and possessive adjectives (My, Your, Their, His, Its, Her, Our). Person deixis consists of three categories. They are first person, second Person and third Person.

b) Spatial Deixis

Spatial Deixis is also call as Place Deixis, where the related place of things and people is being indicated. It mostly is expressed in: This, That, These, Here, There, and Those. Complete references to place detect, a person or an object in a specific latitude and longitude, while relational references locate people and place in terms of each other and the speaker Cummings (2006:26) in (Wiguna et al., 2018).

c) Temporal Deixis

Temporal deixis is also describe Time Deixis. a statement for time relative to a temporal statement point, this point is the moment of expression in which when writing or speaking (Dylgjeri \& Kazazi, 2013) in (Setiakawanti \& Susanti, 2018). Temporal deixis shows the position of actions and facts in time. English have word lexicals and phrases commonly described for temporal deixis, such as English terms today, yesterday, now, then, tomorrow, next year, last year, etc.

\section{Song Lyrics}

Songs is one of media in language to communicate or deliver a message which created by a songs' writer through a singer to listeners. Song is a part of literature (Siallagan, et. al., 2017) 
cited in (Sari, et al., 2019). The song lyrics vary in terms of textual meaning. Usually the hearers have diverse translation to comprehend the meaning of the song. Not all of the words contained in the lyrics can be interpreted if we don't know the physical context of the speakers, such as the here, today, or tomorrow, and the pronouns such as you, them, he, her and, it. Some sentences in English cannot be understood if you do not know who is talking to and what the reference is. Sometimes, there is misunderstanding of meaning and intention between speaker and listener. In order to understand an intended meaning of the speakers, the listeners should be able to identify the meaning and deixis of utterances or sentences.

\section{METHOD}

In this research, researcher used a descriptive qualitative method. According to Perry (2005) as cited in (Asmarita \& Haryudin, 2019) states qualitative research is characterized by the verbal description of its data. According to Taylor (1984) as cited in (Efransyah, 2020) states that qualitative method makes the researcher expand concepts, understanding and observartion from system in the data fairly than appraise preconceived models, theories or hypothesis. This method used to collect, to classified, to analyzed, and to produce conclusion from the data analysis. While the techniques of collecting and analyzing the data are: the first, the researchers listened the song entiltled Level of Concern, the second, print out the song lyric, the third, read the whole parts of song lyrics, then classified and analyzed the kinds of deixis related to the grand theory, and finally calculated the mostly deixis that are used in the song lyric level of concern.

\section{RESULTS AND DISCUSSION}

\section{Results}

The researcher found that the lyrics tend to use such types of deixis which includes personal, spatial, and temporal deixis in Level of Concern song lyrics. The types of deixis used are various and they have different references and meanings. They showed in the table below:

\section{Table 1}

Number of Types of Deixis from the song lyric entitled Level of Concern

\begin{tabular}{lll}
\hline \multicolumn{1}{c}{ Personal } & \multicolumn{1}{c}{ Spatial } & Temporal \\
\hline 1. First person: & 1. This $: 2$ data & 1. Now $: 1$ data \\
I $: 11$ data & & \\
Me $: 20$ data & & \\
My $: 6$ data & & \\
We $: 20$ data & & 2. July $: 1$ data \\
2. Second person & 2. World $: 1$ data & \\
You $: 19$ data & & \\
3. Third person & & \\
It $: 1$ data & & \\
\hline
\end{tabular}

\section{Discussion}

After collecting and classifying the data from the song lyric entitled Level of Concern. They are explained as follow: 
Table 2

Number of Personal Deixis

\begin{tabular}{clcc}
\hline \multirow{2}{*}{ Song } & \multicolumn{3}{c}{ Personal Deixis Word } \\
\cline { 2 - 4 } & \multicolumn{1}{c}{ First Person } & \multicolumn{1}{c}{ Second Person } & \multicolumn{1}{c}{ Third Person } \\
\hline Level Of & $\begin{array}{l}\text { I (11 data), Me (20 } \\
\text { data), My (6 data), We } \\
\text { Concern }\end{array}$ & You (19 data) & It (1 data) \\
& (20 data), I'm (1 data) & & \\
\hline
\end{tabular}

The first will be discussed from the personal deixis from the table above it can be seen the total of personal deixis is 77 data from song lyrics entitled Level of Concern. As it is classify becomes three, personal deixis covers the first, the second, and the third person.

Data 1

The first person

The first personal deixis that found from the song lyric entiled Level of Concern are personal pronoun which consist of "I, Me, My, and We". Those contain in the song lyric such follow: "'Cause I told you my level of concern", "Tell me we're alright, tell me we're okay", "I'm asking you to stay". The first data are "I", "Me", and "My" which refer to the singer Twenty One Pilots. The second data is "We" refers to the singer and the listener.

Data 2

The second person

The second personal deixis that found in the song lyric entitled Level of Concern is "You". It contains in the song lyric such as: "I'm asking You to stay". The function of second person deixis "You" is as a subject of singular pronoun and it refers to the listeners.

Data 3

The third person

The third personal deixis that found from the song lyric entitled Level of Concern is "It". It contains in the song lyric such as: "Or is this the way it ends?". The third personal deixis "It" referes to Covid-19 or Corona virus. The function of third person deixis is as subject of singular pronoun.

Based on the explanation above, the researchers noted that from Level of Concern there are three types of personal deixis which are occured in that song.

2. Spatial or Place Deixis

Table 3

Number of Spatial or Place Deixis

\begin{tabular}{cl}
\hline Song & \multicolumn{1}{c}{ Spatial or Place Deixis Word } \\
\hline Level of Concern & $\begin{array}{l}\text { This (2 data), World (1 } \\
\text { data) }\end{array}$ \\
\hline
\end{tabular}


From the table above, it can be seen that there are 3 data of spatial or place deixis in the song Level of Concern, as it is covered adverbial of manner and place, such in the following explanation:

\section{Data 4}

Spatial Deixis

The first spatial deixis that found from the song lyric entiled Level of Concern is "This". It contains in the song lyric such as: "Or is this the way it ends?". The word "This" refers to the way of quarantine. The function of "This" is an adverbial of manner to indicate the way people to cure theselves in the song lyric.

\section{Data 5}

Spatial Deixis

The second spatial deixis that found from the song lyric entitled Level of Concern is "World". It contains in the song lyric such as: "In a world, where you could just lie to $m e$ ". The function of "World" is an adverbial of place to indicate the used of location in the song lyric.

Based on the explanation above, the researchers noted that from Level of Concern, there are two types of spatial deixis which are occured in that song. The functions of spatial deixis are to indicate the used of adverbial of place and manner in the song lyrics.

3. Temporal or Time Deixis

Table 4

Number of Temporal or Time Deixis

\begin{tabular}{cc}
\hline Song & Temporal or Time Deixis Word \\
\hline Level of Concern & Now (1 data), July (1 data) \\
\hline
\end{tabular}

From the table above, the researchers found 2 data of time deixis which are now and July. Such in the following explanation:

Data 6

Temporal Deixis

Based on the description above, the first data is "Now" which found in the song lyric "I need you now". From the lyric, the word "now" is included in adverbial of time for it shows the information of time in that song.

Data 7

Temporal Deixis

The second data is "July" which exists in the song lyric, "July starts to make me nervous". From the lyric, The word "July" refers to the name of the month that shows the information of time. 
Based on the explanation above, the researchers noted that from Level of Concern. There are two types of temporal deixis which are occured in that song. The function of temporal deixis is to indicate the used of adverbial of time in the song lyrics.

\section{CONCLUSION}

After collecting and analyzing the data, the researchers found several types of deixis from the song lyrics entitled Level of Concern which are personal, spatial, and temporal deixis. The words personal deixis are "I, Me, My, and We" which classified as the first person, "You" as the second person, while It classified as the third person. The second types of deixis is spatial or place deixis which are "This and World" which calssified as adverbial of manner and place. And the last is temporal or time deixis which classified as the third types of deixis. The words are "Now and July" which classified as adverbial of time. While the mostly dominant types of deixis that are used in song lyric entitled Level of Concern are personal deixis ( 77 data), because they represent the singer and the message which wanted to be delivered to the listeners.

\section{ACKNOWLEDGMENTS}

Alhamdulillahirabbil'alamin. First of all, I always thank to Allah because the writer finally finish this article. I also would like to express my gratitude and say many thanks to my family, especially for my parents who always give me spirit, motivation, financial, moral, and spiritual. This article could not be completed without a great deal of help from many people, especially Mr. Efransyah as an advisor who has provided invaluable for the guidance, patient, kindness, contribution, correcting, and helping me in finishing this journal. Without his guidance this article would not be completed well. Then for Mrs. Aseptiana Parmawati, M. Pd., who helped me from submitting to publishing this journal. Thanks are due to all people who have supported and motivated in writing this article, who cannot be mentioned one by one. May Allah blesses you all. Thank you.

\section{REFERENCES}

Asmarita, A., \& Haryudin, A. (2019). An Analysis Deixis in Ridwan Kamil' S Speech at the Asia Africa Conference ( KAA), 2(5), 622-627.

Efransyah, E. (2020). Connotative Meaning in The Proverbs of The Besemah Language (A Sematic Study). Project (Professional Journal of English Education), 3(1), 143. Https://Doi.Org/10.22460/Project.V3i1.P143-148

Joseph, T. (2020). Level of Concern Lyric. Retrieved From Https://Genius.Com/Twenty-OnePilots-Level-Of-Concern-Lyrics

Liawati, A., Rizkiani, S., \& Jamaludin, A. (2020). Deixis in the clever servant story. PROJECT (Professional Journal of English Education), 3(1), 54-58.

Lugina, G., \& Suprijadi, D. (2019). Deixis In The Legend Of Lake Toba Story. PROJECT (Professional Journal of English Education), 2(5), 640-644.

Nasution, D. R. A., Setiadi, G., \& Ilza, S. S. (2018, July). Deixis Analysis in the Song Lyrics of Ed Sheeran'sDivideAlbum. In English Language and Literature International Conference (ELLiC) Proceedings (Vol. 2, pp. 376-382).

Nurjanah, S. Y., Ramdhaniah, A., \& Efransyah, M. (2018). Affixation of derivational and inflectional process in narrative text entitled the Ugly Duckling. PROJECT (Professional Journal of English Education), 1(3), 309-318. 
Sari, H. P., Dartini, N. R., \& Mulyani, E. R. (2019). Interpersonal Meaning Analysis of Adele's Song Lyric in 21 Album. PROJECT: Professional Journal of ENglish Education, 2(1), 93101.

Setiakawanti, R. N., \& Susanti, E. (2019). Analysis Pragmatic Study On Deixis In The Articles Jakarta Sport. PROJECT (Professional Journal of English Education), 1(6), 757-762.

Wiguna, A., Anggraeni, H., Nuramalia, R., \& Sadikin, I. S. (2019). Deixis in Maleficent Movie Script. PROJECT (Professional Journal of English Education), 1(2), 133-138. 